\begin{tabular}{c} 
Brazilian Journal \\
of Chemical \\
Engineering \\
\hline
\end{tabular}

ISSN 0104-6632

Printed in Brazil

www.abeq.org.br/bjche

Vol. 31, No. 01, pp. 9 - 18, January - March, 2014

\title{
THE STIMULATING EFFECTS OF THE ADDITION OF GLUCOSE ON DENITRIFICATION AND REMOVAL OF RECALCITRANT ORGANIC COMPOUNDS
}

\author{
Dong Wang, Min $\mathrm{Ji}^{*}$ and Can Wang \\ Tianjin University, School of Environmental Science and Engineering, Tianjin 300072, China. \\ Phone: + 86-22-27406057, Fax: + 86-22-27406057, \\ E-mail: jimin@tju.edu.cn \\ (Submitted: January 13, 2013 ; Revised: February 23, 2013 ; Accepted: February 26, 2013)
}

\begin{abstract}
A laboratory scale aerobic oxidation ditch combined with an anoxic reactor was conducted to treat wastewater from a chemical industrial park in Tianjin, China. The wastewater exhibited a low biodegradability, and the results of gas chromatography mass spectrometry (GC-MS) analysis showed that some recalcitrant organic components are present in the wastewater. Ammonia nitrogen $\left(\mathrm{NH}_{4}^{+}-\mathrm{N}\right)$ removal efficiency of over $90 \%$ was obtained. However, the removal efficiencies of total nitrogen (TN) and chemical oxygen demand (COD) were below $16 \%$ and $15 \%$, respectively. The addition of glucose to the anoxic reactor in the system increased the removal efficiencies of TN and COD to approximately $72 \%$ and $25.57 \%$, respectively. Results of mass balance indicate that about $60 \%$ of the external carbon was consumed as electron donor for denitrification, while $40 \%$ was consumed as a substrate for co-metabolism. The optimal dose of added glucose was also investigated, which was determined at 0.35 to $1.20\left(\mathrm{COD}_{\text {glucose }}: \mathrm{COD}_{\text {original }}\right)$.

Keywords: Recalcitrant organic compounds; Chemical industrial wastewater; Additional carbon source; Co-metabolism.
\end{abstract}

\section{INTRODUCTION}

In China, most of the industrial wastewater is pretreated through the sewage treatment plants of factories before being discharged to the centralized wastewater treatment plants (CWWTPs) in industrial parks (Lei et al., 2010). Therefore, such integrated industrial wastewater always exhibits several characteristics, such as complex components, toxicity or inhibition of biological treatment systems, and refractoriness to biodegradation. Physical, chemical, and biological processes can be applied to treat this kind of integrated industrial wastewater. Compared with biological processes, physical and chemical processes perform better in removing organic compounds, whereas they require more energy and incur higher costs (Borja et al., 1998). On the other hand, biological processes can degrade and mineralize organic compounds and are cost-effective. However, the toxic or inhibitory effects of recalcitrant compounds in wastewater can affect the efficiency of biodegradation processes (Sen and Demirer, 2003; Eleren and Alkan, 2009). Compounds such as phenol, antibiotics and heavy metals in wastewater have adverse effects on microbes, especially ammonia oxidation bacteria, due to their toxic or inhibitory effects (Ben-Youssef and Vázquez-Rodriguez, 2011; You et al., 2009; Carucci et al., 2006). Meanwhile, a portion of the polycyclic aromatic hydrocarbons (PAHs), azo dyes, surfactants and pharmaceuticals

*To whom correspondence should be addressed 
are persistent in biological wastewater treatment processes (Cheriaa et al., 2008; Ahmad et al., 2010; González et al., 2007; Radjenovic et al., 2007).

The main organic compounds in this kind of integrated industrial wastewater are recalcitrant or refractory compounds. Moreover, the biodegradable carbon sources are insufficient. Thus, the denitrification and the removal of organic compounds is ineffective in conventional biological treatment processes. In addition, the biomass, activity, and morphology of the activated sludge may change in longterm operation. In this case, a biodegradable carbon source is added to the biological treatment processes to improve TN removal and maintain the activated sludge biomass and activity.

Previous studies revealed that the use of additional carbon sources as co-substrate can enhance the biodegradation of recalcitrant compounds, such as chlorophenols, insecticides, PAHs and azo dyes (Xiangchun et al., 2003; Shen et al., 2005; Rentz et al., 2005; Majumder and Gupta, 2008; Blánquez et al., 2008; Bajaj et al., 2008; Ahmad et al., 2010; Shawaqfeh, 2010). However, most of these studies focused on these recalcitrant compounds in synthetic wastewater, and only a few studies have explored the effects of additional carbon sources on complex component degradation in actual integrated industrial wastewater. Moreover, previous studies obtained different results on the optimal stage (aerobic or anoxic) and dose for carbon addition.

This study focuses on the degradation characteristics of industrial wastewater by using a laboratory scale system with a combined anoxic reactor and aerobic oxidation ditch. The performances of nitrogen and organic compound removal with and without the addition of glucose as a carbon source was investigated. The optimal section where glucose was added and the ratio of optimal added glucose were also investigated. These measures can provide economic and efficacious technical support to full-scale industrial wastewater treatment plants.

\section{MATERIALS AND METHODS}

\section{Wastewater Source and Characteristics}

The wastewater was obtained from the influent of a full-scale wastewater treatment plant in a chemical industrial park of Tianjin, China. Over 30 kinds of industrial plants, such as pharmaceutical, manufacturing, chemical, and food and drink processing industries, are situated in the park area. The different waste streams were pretreated prior to being discharged to the CWWTPs, making the wastewater component-complex and difficultly biodegradable. The concentration variation of ammonia and nitrate in the influent is dependent on the pretreatment and intermittent discharge of different sewage by the factories. The characteristics of the wastewater samples are presented in Table 1.

Table 1: Characteristics of the actual wastewater used in the experiment.

\begin{tabular}{|l|r|}
\hline Parameter & \multicolumn{1}{|c|}{ Value } \\
\hline $\mathrm{COD}_{\mathrm{Cr}}$ & $60-180 \mathrm{mg} / \mathrm{L}$ \\
$\mathrm{BOD}_{5}$ & $6-23 \mathrm{mg} / \mathrm{L}$ \\
$\mathrm{BOD}_{5} / \mathrm{COD}_{\mathrm{Cr}}$ & $0.08-0.20$ \\
$\mathrm{TN}$ & $13.4-39.6 \mathrm{mg} / \mathrm{L}$ \\
$\mathrm{NH}_{4}{ }^{-}-\mathrm{N}$ & $1.8-30.5 \mathrm{mg} / \mathrm{L}$ \\
$\mathrm{NO}_{3}{ }^{-} \mathrm{N}$ & $1.7-15.8 \mathrm{mg} / \mathrm{L}$ \\
$\mathrm{TP}$ & $6.4-8.1 \mathrm{mg} / \mathrm{L}$ \\
$\mathrm{Suspended}$ solid & $102-751 \mathrm{mg} / \mathrm{L}$ \\
$\mathrm{pH}$ & $8.02-8.45$ \\
\hline
\end{tabular}

\section{Experiment Set Up}

Figure 1 shows the schematic diagram of the laboratory scale process in this study. The anoxic reactor and the aerobic oxidation ditch were made of Plexiglas and had working volumes of $9 \mathrm{~L}$ and $73 \mathrm{~L}$, respectively. The anoxic reactor was an anoxic biofilm reactor with a biomass carrier that accounts for $30 \%$ of the reactor volume.

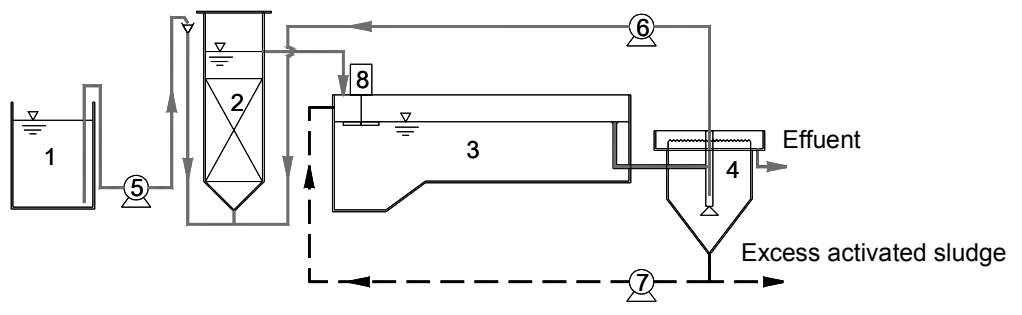

1. influent tank,

2. anoxic reactor,

3. aerobic oxidation ditch reactor,

4. secondary sedimentation tank,

5. influent peristaltic feed pump,

6. effluent circumfluence pump,

7. activated sludge recycle pump,

8. surface aerator

Figure 1: Schematic diagram of the experimental process 
The flocculent seed sludge in the reactor was obtained from the anoxic tank and oxidation ditch of a full-scale wastewater treatment plant in the industrial park. During the start-up stage (15 days), the mixed liquor suspended solids (MLSS) were kept at approximately $10.0 \mathrm{~g} / \mathrm{L}$ in the anoxic reactor and $3.0 \mathrm{~g} / \mathrm{L}$ in the aerobic oxidation ditch. The recycle flow rate was $200 \%$ of the influent. The influent wastewater was mixed with glucose to cultivate and enrich the activated sludge, and then glucose was decreased gradually, so that the influent was only the industrial wastewater at the end of the start-up stage.

\section{Operation Conditions}

The process operating condition is shown in Table 2. During the experimental stage, the performances of COD and nitrogen removal with and without the addition of external carbon (a concentrated solution of glucose, $5000 \mathrm{mg} / \mathrm{L}$ ) were investigated. The concentrated solution of glucose was pumped and mixed with the wastewater influent. The flux of glucose solution was much lower than the flux of wastewater influent. Hence, the influence of flux can be neglected. The glucose COD in the mixed influent was increased from $10.40 \mathrm{mg} / \mathrm{L}$ to $354.14 \mathrm{mg} / \mathrm{L}$ during Stage 2. COD removal efficiency during the glucose addition phase was the original COD removal efficiency without the COD of the additional glucose.

During Stage 1, the operating condition was optimized by varying the hydraulic retention time (HRT) from $12 \mathrm{~h}$ to $48 \mathrm{~h}$. During Stage 2, glucose was added to the aerobic oxidation ditch at the beginning (day 92 to day 104). From day 105 to day 138, glucose was added to the anoxic reactor.

\section{Wastewater Quality Analysis}

The following procedure was performed during the experiment. First, the influents and effluents of each reactor were collected and tested for parameters following standard methods (National Environment Bureau Water Wastewater Monitoring Analysis Committee, 2002). COD was measured using the potassium dichromate oxidation method. $\mathrm{BOD}_{5}$ was determined using fast BOD measuring devices (OxiTOP IS6, Germany). A spectrophotometer (HACH DR2800, USA) was used to measure ammonia nitrogen, nitrate, and $\mathrm{TN}$ concentrations. $\mathrm{pH}$ and dissolved oxygen (DO) levels were detected daily (HACH sension156, USA).

The compositions of organic compounds in the wastewater were analyzed using GC-MS. The samples were pretreated by $\mathrm{CH}_{2} \mathrm{Cl}_{2}$ (Fisher Corporation, USA) liquid-liquid extraction and extracted under acidic, neutral, and alkaline conditions, which were conducted using the extraction procedure proposed by Lai et al. (2008). Then, $1 \mu \mathrm{L}$ of the pretreated sample was injected into the GC-MS system (GC: 6890N; MS: 5975C, Agilent; USA). The carrier gas was pure helium gas $(99.999 \%)$ with a flow rate of $1 \mathrm{~mL} / \mathrm{min}$. A DB-35MS capillary column with an inner diameter of $0.25 \mathrm{~mm}$ and length of $30 \mathrm{~m}$ was used in the separation system. The temperature control program was performed as follows: $40^{\circ} \mathrm{C}$ was maintained for $3 \mathrm{~min}$ and then increased to $280{ }^{\circ} \mathrm{C}$ at a rate of $4{ }^{\circ} \mathrm{C} / \mathrm{min}$. The temperature in the oven was maintained at $280{ }^{\circ} \mathrm{C}$ for $15 \mathrm{~min}$. Organic compound analysis was conducted with reference to the NIST05 mass spectral library database.

Table 2: Operating conditions of the laboratory scale system.

\begin{tabular}{|c|c|c|c|c|}
\hline \multirow{2}{*}{ Stage } & Operating condition & HRT(h) & Operation Period & \multirow[t]{2}{*}{ COD Remova } \\
\hline & Start-up stage & 24 & 15 Days & \\
\hline \multirow{4}{*}{1} & \multirow{4}{*}{ Operating condition optimization } & 12 & Day 01 - Day 21 & $9.49 \%$ \\
\hline & & 24 & Day 22 - Day 41 & $12.59 \%$ \\
\hline & & 36 & Day 42 - Day 67 & $14.94 \%$ \\
\hline & & 48 & Day 68 - Day 91 & $15.06 \%$ \\
\hline \multirow{2}{*}{2} & \multirow{2}{*}{ Glucose as additional carbon } & 36 & Day 92 - Day 104 & $14.46 \%$ \\
\hline & & 36 & Day 105 - Day 138 & $25.57 \%$ \\
\hline
\end{tabular}




\section{RESULTS AND DISCUSSION}

\section{The Characteristics and Biodegradation of the Wastewater}

The wastewater COD varied between $60 \mathrm{mg} / \mathrm{L}$ and $180 \mathrm{mg} / \mathrm{L}$, and $\mathrm{BOD}_{5}$ was in the range of approximately $6 \mathrm{mg} / \mathrm{L}$ to $23 \mathrm{mg} / \mathrm{L}$. The $\mathrm{BOD}_{5} / \mathrm{COD}$ ratio was approximately $0.08-0.2$, which was too low to allow biological treatment.

Results of the GC-MS analysis show that some of the organic compounds in the wastewater influent were phenols, Benzene, Toluene, Ethylbenzene and Xylene (BTEX), nitrogen heterocyclic compounds (such as benzothiazole), and PAHs (such as naphthalene), all of which are recalcitrant to biological degradation (Table 3). Therefore, biodegradable carbon was insufficient in the wastewater sample, and most of the organic compounds were refractory compounds.

Table 3: The main organic compounds in the wastewater used in the experiment.

\begin{tabular}{|l|c|c|}
\hline \multicolumn{1}{|c|}{ Organic compounds } & $\begin{array}{c}\text { Average } \\
\text { percentage*1 } \\
\text { (\%) }\end{array}$ & $\begin{array}{c}\text { Number of } \\
\text { Appearances* } \\
\text { (11 samples) }\end{array}$ \\
\hline 2-Methyl-3-bromo-2-butanol & 1.453 & 4 \\
Aniline, N-methyl- & 2.656 & 6 \\
Benzothiazole & 1.429 & 5 \\
Formamide, N-methyl-N-phenyl- & 1.795 & 6 \\
Butylated Hydroxytoluene & 3.214 & 5 \\
Benzothiazole, 2-(methylthio)- & 1.207 & 4 \\
Cyclic octaatomic sulfur & 31.89 & 6 \\
Dibutyl phthalate & 1.361 & 4 \\
Betamethasone & 3.789 & 4 \\
Cholest-5-en-3-ol (3.beta.)- & 16.66 & 10 \\
1-Piperazineethanamine & 0.568 & 3 \\
Naphthalene & 1.698 & 3 \\
Dimethyl phthalate & 0.967 & 4 \\
Tert-butyldimethylsilyl ester & 1.065 & 3 \\
Phenol, 4-(1,1-dimethylpropyl)- & 2.876 & 3 \\
Triethyl phosphate & 8.166 & 4 \\
Phenol, p-tert-butyl- & 4.216 & 3 \\
\hline
\end{tabular}

*1 Average percentage that the compounds account for in the total peak area;

*2 Times that the organic matter appeared in the GC-MS analysis during the experiment.

\section{The Performance of Nitrogen and COD Removal in the Combined System}

Fig. 2 (stage 1) and Fig. 3 (stage 1) show the performances of $\mathrm{NH}_{4}{ }^{+} \mathrm{N}$, nitrate nitrogen $\left(\mathrm{NO}_{3}{ }^{-} \mathrm{N}\right)$,
$\mathrm{TN}$, and COD removal in the proposed system. In stage 1 , the influent $\mathrm{NH}_{4}{ }^{+}-\mathrm{N}$ was $11 \mathrm{mg} / \mathrm{L}$ to $31 \mathrm{mg} / \mathrm{L}$ and the effluent was approximately $1 \mathrm{mg} / \mathrm{L}$ because of the long sludge retention time, which is suitable for the growth of nitrifiers (Moussa et al., 2006). In addition, the influent disturbance of ammonia and nitrate on day 58 was due to the pretreatment and intermittent discharge of a different waste steam.

The operating conditions were optimized by varying the hydraulic retention time (HRT) from $12 \mathrm{~h}$ to $48 \mathrm{~h}$. According to the COD removal efficiency, $\mathrm{HRT}=36 \mathrm{~h}$ was optimal. However, the removal efficiencies of TN and COD were not greater than 16\% and $15 \%$, respectively, because the amount of biodegradable carbon in the wastewater was insufficient. Hence, denitrification and COD removal had extremely low efficiencies.

\section{Effect of Additional Glucose on System Performance}

Stage 2 of Fig. 2 and Fig. 3 shows the system performance with glucose addition. As can be seen in Fig. 2, the external glucose added to the system had an adverse effect on the performance of ammonia removal. However, the final effluent $\mathrm{NH}_{4}{ }^{+} \mathrm{N}$ was approximately $1 \mathrm{mg} / \mathrm{L}$. TN removal efficiency increased immediately after the addition of glucose to the anoxic reactor (day 105 to day 138). TN removal efficiency was enhanced and good performance was maintained with increasing doses of additional glucose because glucose provided enough electron donor during the denitrification process. During the stable stage, TN removal efficiency remained unchanged at an average of approximately $72.01 \%$, even when the dosage of additional carbon was significantly increased.

As can be seen in Fig. 3, glucose was added to the aerobic oxidation ditch at the beginning of stage 2 (day 92 to day 104). The total COD and original COD removal was inefficient and did not increase compared with the removal efficiency in Stage 1. However, glucose was added to the anoxic reactor from day 105 to day 138. The total COD removal efficiency was increased from $23.93 \%$ to $85.71 \%$ and the degradation of external glucose contributed to the high removal efficiency of total COD. The addition of glucose resulted in an apparent increase in the organic compound removal and some recalcitrant compounds were transformed, thereby producing $25.57 \% \mathrm{COD}_{\text {original }}$ removal efficiency and a final effluent with $66.3 \mathrm{mg} \mathrm{COD} / \mathrm{L}$ on average. 

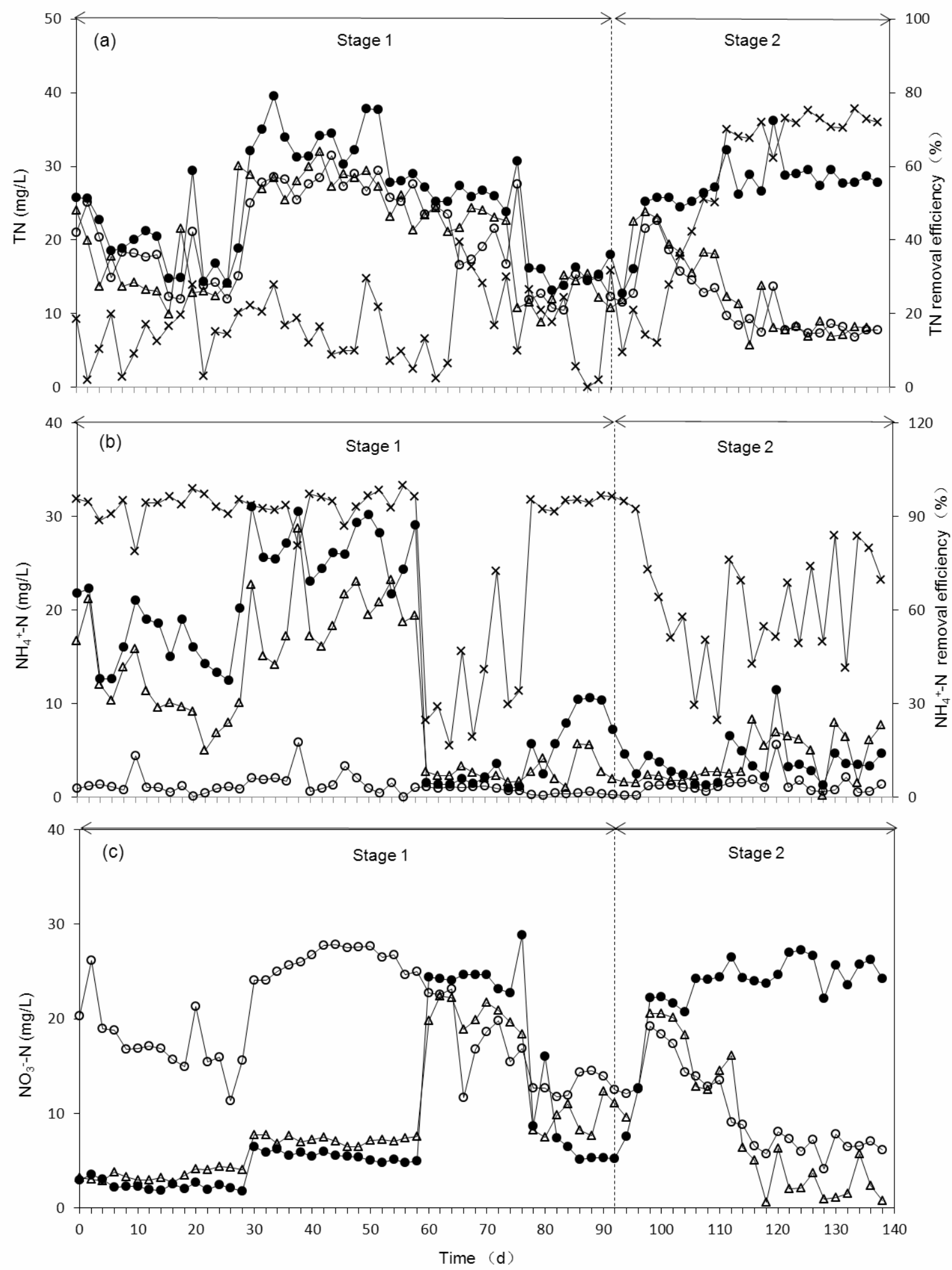

Figure 2: $\mathrm{TN}, \mathrm{NH}_{4}{ }^{+}-\mathrm{N}$, and $\mathrm{NO}_{3}^{-}-\mathrm{N}$ removal in the system: $(\bullet)$ influent, $(\Delta)$ anoxic reactor effluent, $(\circ)$ oxidation ditch effluent, and $(\times)$ removal efficiency 

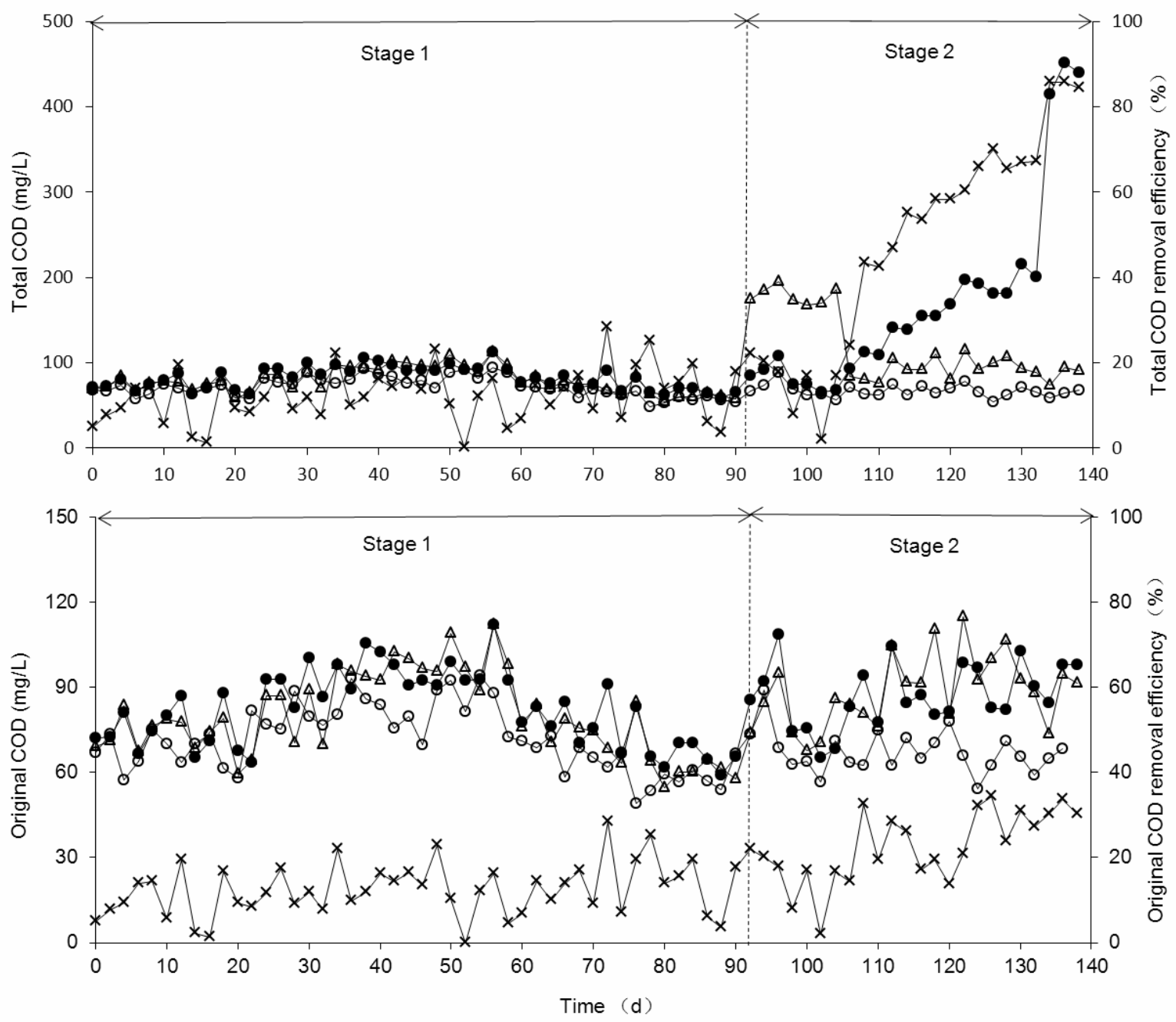

Figure 3: COD removal in the system: $(\bullet)$ influent, $(\Delta)$ anoxic reactor effluent, $(\circ)$ oxidation ditch effluent, and $(\times)$ removal efficiency

\section{Effect of Glucose Addition to the Different Sections of the System}

The effect of adding glucose to the different sections of the system was analyzed, as shown in Fig. 4. The system performances with glucose added to the aerobic oxidation ditch and the anoxic reactor were compared with the system performances without the addition of glucose. As can be seen in Fig. 4, the TN removal efficiency increased when glucose was added to the anoxic reactor. However, the TN removal efficiency remained constant despite the addition of glucose to the aerobic oxidation ditch. On the other hand, the COD removal efficiency apparently increased when glucose was added to the anoxic reactor. The performance of COD removal did not change significantly regardless of whether glucose was added to the aerobic oxidation ditch or not.

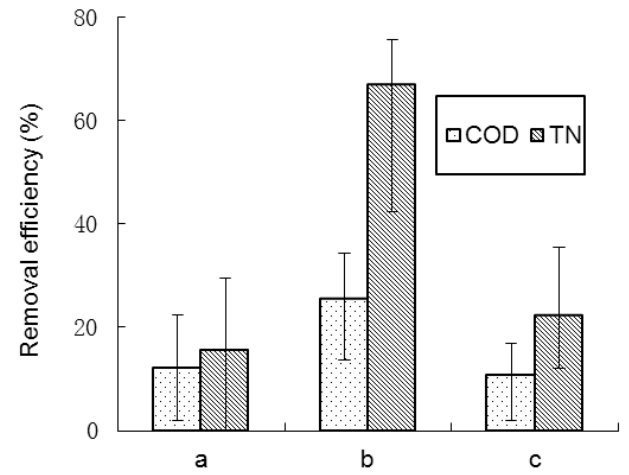

Figure 4: Various COD and TN removal efficiencies: a - average removal efficiency without added glucose; b - average removal efficiency with the addition of glucose to the anoxic reactor; $\mathrm{c}$ - average removal efficiency with the addition of glucose to the aerobic oxidation ditch 
This result illustrates that the addition of glucose as electron donor to the anoxic reactor can enhance the denitrification process. Furthermore, the recalcitrant organic compounds in the wastewater may be transformed under anoxic or anaerobic conditions by using glucose as co-substrate. The literature indicates that the aromatic structure of compounds can be metabolized under anoxic or anaerobic conditions (Young and Haggblom, 1990). However, the degradation rate of such compounds by microbes is slow, as the energy required for bacterial growth is not adequate from such recalcitrant compounds (Ghosh and Philip, 2004). Additional carbon can provide the primary energy and carbon source for microbe metabolism (Christiansen et al., 1995). In such a case, the co-metabolic enzymes required for the transformation of refractory compounds are induced. The energy quickly regenerates with the rapid metabolism of glucose, which, in turn, can be used to transform refractory compounds (Bali and Sengül, 2002; Wang et al., 2007). However, in this study, the addition of glucose to the aerobic phase only provided a carbon source for the growth and metabolism of the heterotrophs.

\section{The Effect of the $\mathrm{COD}_{\text {glucose }}: \mathrm{COD}_{\text {original }}$ Ratio on COD and TN Removal Efficiencies}

The optimal ratio of $\mathrm{COD}_{\text {glucose }}: \mathrm{COD}_{\text {original }}$ was also investigated (Fig. 6). As can be seen in Fig. 5, the TN removal efficiency significantly increased when the $\mathrm{COD}_{\text {glucose }}: \mathrm{COD}_{\text {original }}$ ratio increased from 0 to 0.35 . However, the increase of $\mathrm{TN}$ removal efficiency became slow but remained stable when the $\mathrm{COD}_{\text {glucose }}: \mathrm{COD}_{\text {original }}$ ratio was increased sequentially. Moreover, the original COD removal efficiency also increased slightly when the $\mathrm{COD}_{\text {glucose }}$ : $\mathrm{COD}$ original ratio was increased from 0 to 1.2 . This is because additional glucose was utilized for the denitrification and co-metabolism of recalcitrant compounds. The original COD removal efficiency gradually stabilized when the $\mathrm{COD}_{\text {glucose }} \mathrm{COD}$ original ratio was increased from 1.2 to 4.0. The recalcitrant compounds that could be co-metabolized with glucose were degraded completely and residuals were non-degradable. The rest of the glucose was utilized by the heterotrophic bacteria. Hence, excessive addition of glucose is not economical for full-scale wastewater treatment plants, and the optimal ratio of $\mathrm{COD}_{\text {glucose }}: \mathrm{COD}_{\text {original }}$ ranged from 0.35 to 1.2 .

\section{Nitrogen and Organic Compound Consumption Analyses in the System}

Nitrogen and organic materials consumption mass balance was analyzed to reveal the characteristics of nitrogen and organic compound transformation with and without the addition of glucose in the system (Fig. 6 and Fig. 7). Without additional glucose, nitrate removal was limited due to insufficient carbon source, and most of the biodegradable organic materials metabolized in raw wastewater were utilized by denitrification under the anoxic condition. However, the insufficient biodegradable COD contributed to the low efficiency of original COD removal.

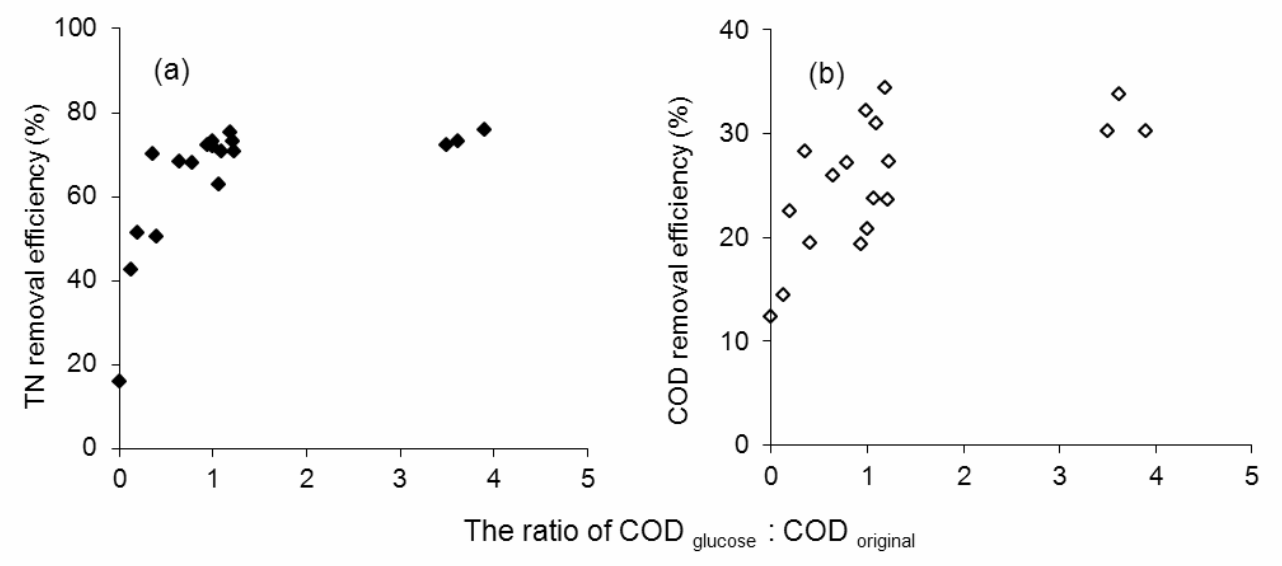

Figure 5: The relationship between removal efficiency and dosage of additional glucose 
When the external carbon was added to the anoxic reactor, most of the additional glucose was consumed by denitrification and metabolism as a cosubstrate. A portion of the refractory compounds, which were persistent without external carbon as cosubstrate, were transformed primarily under the anoxic condition and degraded in the aerobic oxidation ditch reactor.
When $\mathrm{COD}_{\text {glucose }}: \mathrm{COD}_{\text {original }}=0$ and $1.2,60 \%$ of the external carbon was consumed as substrate for denitrification ( $1 \mathrm{mg}$ COD consumption needs 0.35 $\mathrm{mg} \mathrm{NO}_{3}{ }^{-}-\mathrm{N}$ during the denitrification process), while $40 \%$ of external carbon was consumed as substrate for co-metabolism. However, without external carbon, most of the biodegradable COD was consumed as substrate for denitrification in the anoxic reactor.
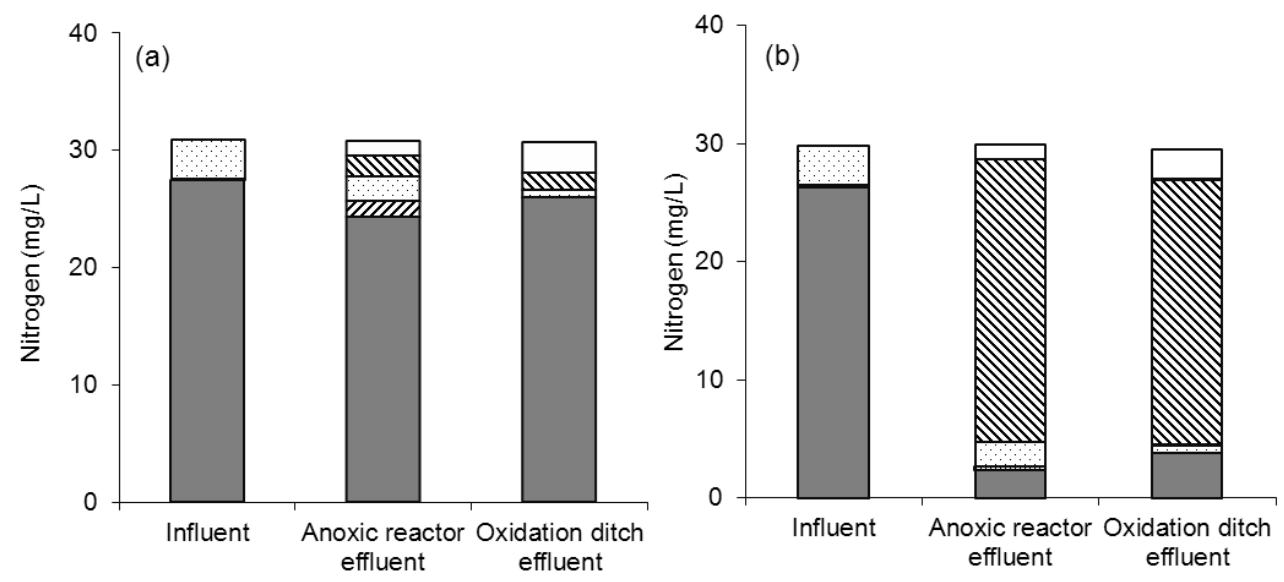

$\square$ Nitrate $\square$ Nitrite $\square$ Ammonia - nitrogen $\mathbf{v}$ Nitrate loss $\square$ Ammonia - nitrogen loss

Figure 6: Nitrogen mass balance analysis in the system: (a) nitrogen mass balance without additional glucose; (b) nitrogen mass balance with additional glucose. Loss of nitrogen was calculated according to the masses of the influent and effluent in the system with $\mathrm{COD}_{\text {glucose }}: \mathrm{COD}_{\text {original }}=0$ and 1.2

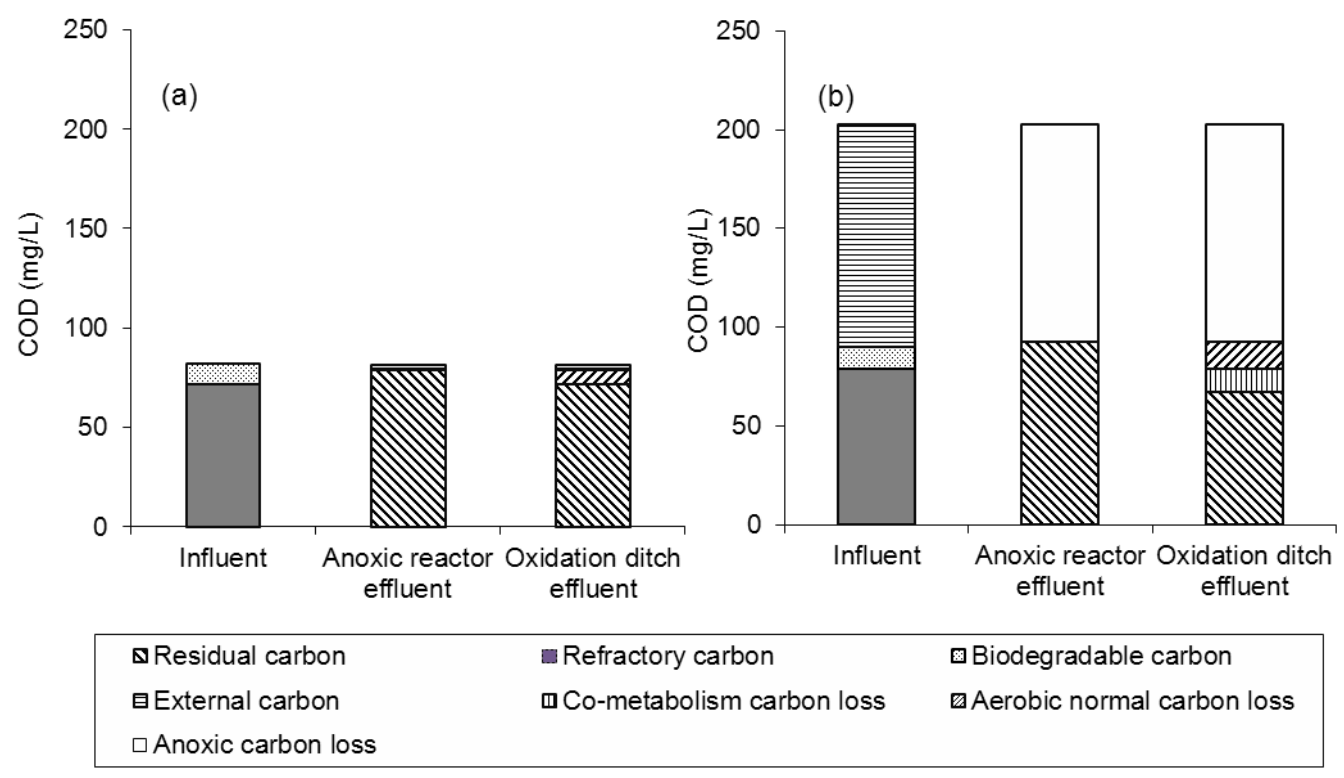

Figure 7: Organic material consumption mass balance analysis in the system: (a) organic material loss without additional glucose; (b) organic material loss with additional glucose. Loss of organic materials was calculated according to the masses of the influent and effluent in the system with $\mathrm{COD}_{\text {glucose }}: \mathrm{COD}_{\text {original }}=0$ and 1.2 . 


\section{CONCLUSIONS}

This study was conducted through a laboratory scale process to investigate the biological treatment performance of integrated industrial wastewater from a chemical industrial park in Tianjin, China. The wastewater was refractory to biodegradation according to the results of the $\mathrm{BOD}_{5} / \mathrm{COD}$ and $\mathrm{GC}-\mathrm{MS}$ analyses. Hence, the COD and TN removal efficiencies did not exceed $15 \%$ and $16 \%$, respectively. Glucose was added to the process as an additional carbon source. No obvious increases of COD and TN removal efficiencies were observed when glucose was added to the aerobic reactor. However, when glucose was added to the anoxic reactor, the $\mathrm{TN}$ removal efficiency increased immediately to $72 \%$ and the COD removal efficiency apparently increased to $25.57 \%$. Results of mass balance show that the external carbon was consumed by cometabolism and denitrification. Some recalcitrant compounds were transformed, which were persistent in the wastewater. Hence, the original COD removal showed a better performance. Moreover, the optimal additional carbon dosage was in the ratio of COD glucose: $\mathrm{COD}_{\text {original }}=0.35-1.2$.

\section{ACKNOWLEDGMENTS}

The authors wish to thank the support from the Science and Technology Support Project of Tianjin, China (No. 12ZCZDSF01800).

\section{NOMENCLATURE}

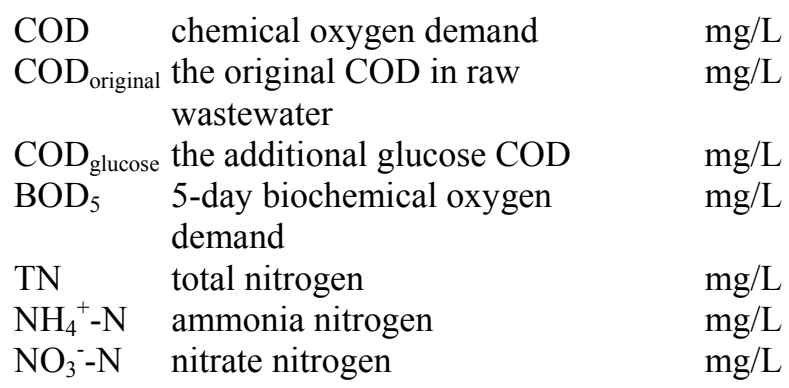

\section{REFERENCES}

Ahmad, R., Mondal, P. K. and Usmani, S. Q., Hybrid UASFB-aerobic bioreactor for biodegradation of acid yellow-36 in wastewater. Bioresource Technolongy, 101, No. 10, 3787 (2010).
Bajaj, M., Gallert, C. and Winter, J., Effect of cosubstrates on aerobic phenol degradation by acclimatized and non-acclimatized enrichment cultures. Engineering in Life Sciences, 8, No. 2, 125 (2008).

Bali, U. and Sengül, F., Performance of a fed-batch reactor treating a wastewater containing 4-chlorophenol. Process Biochemistry, 37, No. 11, 1317 (2002).

Ben-Youssef, C. and Vázquez-Rodriguez, G.A., Model-based design of different fed batch strategies for phenol degradation in acclimatized activated sludge cultures. Bioresource Technology, 102, No. 4, 3740 (2011).

Blánquez, P., Sarrà, M. and Vicent, T., Development of a continuous process to adapt the textile wastewater treatment by fungi to industrial conditions. Process Biochemistry, 43, No. 1, 1 (2008).

Borja, R., Alba, J., Mancha, A., Martin, A., Alonso, V. and Sanchez, E., Comparative effect of different aerobic pretreatments on the kinetics and macroenergetic parameters of anaerobic digestion of olive mill wastewater in continuous mode. Bioprocess Engineering, 18, No. 2, 127 (1998).

Carucci, A., Cappai, G. and Piredda, M., Biodegradability and toxicity of pharmaceuticals in biological wastewater treatment plants. Journal of Environmental Science and Health Part A-Toxic/ Hazardous Substances \& Environmental Engineering, 41, No. 9, 1831 (2006).

Cheriaa, J., Mosrati, R., Ladhari, N. and Bakhrouf, A., Acclimated biomass that degrades sulfonated naphthalene formaldehyde condensate. Pakistan Journal of Biological Sciences, 11, No. 12, 1588 (2008).

Christiansen, N., Hendriksen, H. K., Jarvinen, K. T. and Ahring, B. K., Degradation of chlorinated aromatic compounds in UASB reactors. Water Science and Technology, 31, No. 1, 249 (1995).

Eleren, S. Ç., and Alkan, U., Reducing effect of aerobic selector on the toxicity of synthetic organic compounds in activated sludge process. Bioresource Technology, 100, No. 23, 5714 (2009).

Ghosh, P. K. and Philip, L., Atrazine degradation in anaerobic environment by a mixed microbial consortium. Water Research, 38, No. 9, 2277 (2004).

González, S., Barceló, D. and Petrovic, M., Advanced liquid chromatography-mass spectrometry (LCMS) methods applied to wastewater removal and the fate of surfactants in the environment. TrAC Trends in Analytical Chemistry, 26, No. 2, 116 (2007). 
Lai, P., Zhao, H. Z., Ye, Z. F. and Ni, J. R., Assessing the effectiveness of treating coking effluents using anaerobic and aerobic biofilms. Process Biochemistry 43, No. 3, 229 (2008).

Lei, G., Ren, H., Ding, L., Wang, F. and Zhang, X., A full-scale biological treatment system application in the treatment wastewater of pharmaceutical industrial park. Bioresource Technology, 101, No. 15, 5852 (2010).

Majumder, P. S. and Gupta, S. K., Degradation of 4chlorophenol in UASB reactor under methanogenic conditions. Bioresource Technology, 99, No. 10, 4169 (2008).

Moussa, M. S., Sumanasekera, D. U., Ibrahim, S. H., Lubberding, H. J., Hooijmans, C. M., Gijzen, H. J. and van Loosdrecht, M. C. M., Long term effects of salt on activity, population structure and floc characteristic in enriched bacterial cultures of nitrifiers. Water Research, 40, No. 7, 1377 (2006).

National Environment Bureau Water Wastewater Monitoring Analysis Committee. 2002 Water and Wastewater Monitoring Analysis Method. Beijing, (2002).

Radjenovic, J., Petrovic, M. and Barceló, D., Advanced mass spectrometric methods applied to the study of fate and removal of pharmaceuticals in wastewater treatment. Trends in Analytical Chemistry, 26, No. 11, 1132 (2007).

Rentz, J. A., Alvarez, P. J. and Schnoor, J. L., Benzo $[\alpha]$ pyrene co-metabolism in the presence of plant root extracts and exudates: Implications for phytoremediation. Environmental Pollution, 136, No. 3, 477 (2005).

Sen, S. and Demirer, G. N., Anaerobic treatment of real textile wastewater with a fluidized bed reactor. Water Research, 37, No. 8, 1868 (2003).

Shawaqfeh, A. T., Removal of pesticides from water using anaerobic-aerobic biological treatment. Chinese Journal of Chemical Engineering, 18, No. 4, 672 (2010).

Shen, D. S., Liu, X. W. and Feng, H. J., Effect of easily degradable substrate on anaerobic of pentachlorophenol in an upflow anaerobic sludge blanket (UASB) reactor. Journal of Hazardous Materials, 119, No. 1, 239 (2005).

Wang, S. G., Liu, X. W., Zhang, H. Y., Gong, W. X., Sun, X. F. and Gao, B. Y., Aerobic granulation for 2,4-dichlorophenol biodegradation in a sequencing batch reactor. Chemosphere, 69, No. 5, 769 (2007).

Xiangchun, Q., Hanchang, S., Yongming, Z., Jianlong, W., and Yi, Q. Biodegradation of 2,4-dichlorophenol in an air-lift honeycomb-like ceramic reactor. Process Biochemistry, 38, No. 11, 1545 (2003).

You, S. J., Tsai, Y. P. and Huang, R. R. Y., Effect of heavy metals on nitrification performance in different activated sludge processes. Journal of Hazardous Materials, 165, No. 1, 987 (2009).

Young, Y. L. and Haggblom, M. M, Biotechnology and Biodegradation, The anaerobic microbiology and biodegradation of aeromatic compounds, 450670 (1990). 